\title{
Social Conflict and Change in the Mining Communities of North-West Derbyshire, c. 1600-1700
}

\author{
ANDY WOOD
}

Summary: Increased demand for lead on both domestic and international markets spurred on technological and organizational innovation in Derbyshire's lead mining industry. Population expanded due to immigration into the mining areas, and problems of poverty and proletarianization were created as the traditional small producers were marginalized by new capitalized mineworkings owned by aristocrats, merchants and gentlemen. Social conflict intensified over the ownership of mining rights; in particular, this dispute revolved around popular and élite notions of property and legality. This conflict engendered new forms of popular resistance and provides evidence of a language of class in the seventeenth century. The eighteenth century saw the marginalization of the independent free miner, but memories of lost liberties conditioned the class consciousness of Derbyshire's new working class at the end of the century.

Since the late 1970s a new impetus has been given to the construction of a social history of early modern England. Significant contributions have been made to the study of social structure, crime, sexuality, familial relations, popular disorder, witchcraft and a host of other related aspects of the lives of early modern England's inhabitants. ${ }^{1}$ Despite this renaissance in early modern social history, certain areas of human experience in this period remain obscured. One such example is the lack of attention directed by social historians to the process of industrialization and the experiences of industrial workers in this period. ${ }^{2}$ This neglect is partially the product of a thematic division between the "social" and the "economic" in early modern English studies. Matters social appear to be regarded by many traditional economic historians as peripheral to an account of industrial

' Sec, for example, J. A. Sharpe, Crime in Seventeenth-Century England (Cambridge, 1983), K. E. Wrightson, English Society, 1580-1680 (London, 1982), R. A. Houlbrooke The English Family, 1450-1700 (London, 1984), R. B. Manning, Village Revolts: Social Protest and Popular Disturbance in England, 1509-1640 (Oxford, 1988), A. Macfarlane, Witchcraft in Tudor and Stuart England (London, 1970), B. Reay (cd.), Popular Culture in Seventeenth-Century England (London, 1985).

2 This is less the case as regards European industrialization in the early modern period; sec, for instance, R. Braun, Industrialisation and Everyday Life (Cambridge, 1990) and the extensive literature generated by the proto-industrialization debate.

International Review of Social History 38 (1993), pp. 31-58 
and agrarian change, or the development of trade. ${ }^{3}$ Similarly, social history can tend to relegate matters economic to a dull statistical backdrop to the truly interesting activities of the people of early modern England: crime, deviance, bastardy, riot and the like. In consequence, a vital aspect of the lives of many individuals in this period has been marginalized: the manner in which economic change forced alterations in patterns of work and leisure, altered traditions and customs, remodelled social structures and transformed social relations. Such change is difficult to explain satisfactorily without recognition of the interconnected nature of economic processes, popular culture and social structure. ${ }^{4}$ In particular, the social impact of the expansion and reorganization of a number of England's extractive industries has been neglected by historians. ${ }^{3}$ This is unfortunate, since the particular circumstances of mining prompted the development of capitaland labour-intensive workings much earlier than in other areas of industrial activity. ${ }^{6}$ The study of social change in early modern mining communities can therefore illuminate fundamental aspects both of the industrialization process and of class formation and social identity in that period.

This article will deal specifically with the lead mining industry of Derbyshire. There already exists an extensive literature dealing with technological and economic change in Derbyshire lead mining. ${ }^{7}$ The social context of such change has yet to be written. ${ }^{8}$ In this article I shall attempt

${ }^{3}$ See, for example, the scant attention given to social matters in C. G. A. Clay, Economic Expansion and Social Change: England 1500-1700, 2 vols. (Cambridge, 1984).

- There are, of course, significant exceptions: for example, Wrightson, English Society, J. Rule, The Vital Century: England's Developing Economy, 1714-1815 and Albion's People: English Society, 1714-1815 (both London, 1992), and the various contributions in T. H. Aston and C. H. E. Philpin (eds.), The Brenner Debate: Agrarian Class Structure and Economic Development in Pre-Industrial Europe (Cambridge, 1985).

s An important exception is $\mathrm{D}$. Levine and $\mathrm{K}$. Wrightson, The Making of an Industrial Society: Whickham, 1560-1765 (Oxford, 1991).

- This was particularly the case as regards metal mines. Clay, Economic Expansion, II, pp. 57-58; D. C. Coleman, The Economy of England, 1450-1750 (Oxford, 1977), p. 87.

'See various articles in the BPDMHS, especially J. H. Ricuwerts, "The History of Odin Mine", 6 April 1976; R. Flindall and A. Hayes, "Notes on Some Early Techniques", 6 February 1975; R. Flindall, "Lead Mining in Cromford 1698-1714", 5 February 1975; also J. H. Rieuwerts, "A Technological History of the Drainage of the Derbyshire Lead Mines", unpub. Ph.D. thesis (Leicester University, 1982); I. S. W. Blanchard, "Economic Change in Derbyshire in the Latc Middle Ages", unpub. thesis (London University, 1967); D. Kiernan, The Derbyshire Lead Industry in the Sixteenth Century (Derbyshire Record Socicty, 1989). Abbreviations used in the footnotes are given at the end of the article.

- Various works make passing reference to social change in the Derbyshire mining areas; sec, for example, C. Hill, Reformation to Industrial Revolution (London, 1976), p. 172; J. Thirsk, "Industries in the Countryside" in F. J. Fisher (ed.), Essays in the Economic and Social History of Tudor and Stuart England (Cambridge, 1961), p. 73. The only published piece of rescarch which deals directly with social change in north-west Derbyshire in the early modern period is J. R. Dias, "Lead, Socicty and Politics in Derbyshire before the Civil War", Midland History, 6 (1981). Dias' essay is unreliable at points, and its treatment of social and economic matters is cursory. 
to demonstrate how technological and organizational innovations in the mining and smelting of lead ore interacted with the power relations prevalent between ruler and ruled in the lead fields of north-west Derbyshire. The establishment of capitalist domination over all aspects of lead production and distribution by the eighteenth century was the result of neither an accidental nor an organic process. Rather, the shift from small-scale independent free mining to the labour- and capital-intensive works which accounted for much of Derbyshire's lead production in the eighteenth century was preceded by over a century of conflict between independent small producers and a coalition of gentlemen and aristocrats. Crucially, capitalist production arose from the suppression or limitation of those popular rights and liberties which were seen to operate against the unrestricted expansion of élite control over the extraction of lead ore.'

The mining and smelting of lead was one of England's most important industries in the seventeenth century, serving markets in England, Europe and the New World; at times the value of its exports was exceeded only by that of cloth. ${ }^{10}$ The largest lead field lay in north-west Derbyshire, where at least 4,000 workers were directly employed in extraction by 1640 , about half of whom were waged labourers. " The rest were independent small producers, the free miners who had traditionally dominated the mining of lead but whose importance was declining.

The classic free miner owned the small-scale mine in which he worked, sometimes in partnership with two or three other miners, and seems to have regarded mining as a supplement to income derived from agriculture. ${ }^{12}$ In the transport and dressing of ore the free miner employed underground "carriers" and surface workers, the latter being almost exclusively women and children. Often mining would be a family enterprise, the husband working with a brother or elder son while his wife and children laboured on the surface. ${ }^{13}$ This sexual division of labour ensured maximum patriarchal control over the skilled element of production and remained one of the enduring facets of the mining industry whether in capitalized workings or small-scale production. ${ }^{14}$ Women remained excluded from

- For a recent study of social conflict over custom in a largely agrarian context, see E. P. Thompson, "Custom, Law and Common Right", in Ciustoms in Common (London, 1991). In a later industrial context, see C. Fisher, Custom, Work and Market Capitalism: The Forest of Dean Colliers 1788-1888 (London, 1981).

${ }^{10}$ Kicrnan, Lead Industry, pp. 1-2, 85-118; PRO SP29/433/31; PRO SP14/109/164; PRO SP16/341/130; Clay, Economic Expansion, pp. 57-58.

"PRO E101/280/18.

12 I. S. W. Blanchard, "Labour Productivity and Work Psychology in the English Mining Industry, 1400-1600", Economic History Review, 31, 1978; Kiernan, Lead Industry, pp. 339; R. Sharpe France (cd.), "The Thieveley Lead Mines 1629-35", Lancashire and Cheshire Record Society 102, (1947), pp. 7, 24; PRO DLA1/17/19.

13 PRO DL41/17/19; PRO E134/4 Chas I/Mich 33; E134/3 Jas II/East 15; PRO E134/2 Jas II/Mich 21; PRO DLA/75/10; PRO DL4/124/16867.

" SRO Bag.C.3508; SRO OD 1495; DRO D258/31/58; PRO RGO/33. 
control over the industry, save for their inheritance in widowhood of mine workings ${ }^{15}$ they could not hold office in the miners' court, the Barmote, and rarely took part in legal or crowd actions in defence of mining rights. ${ }^{16}$ The struggle for the control of the mining industry which occurred during the seventeenth century was one which took place almost exclusively between contending groups of men.

In the middle of the sixteenth century the mining of lead was largely concentrated within the Wapentake of Wirksworth; the vast majority of lead was extracted by the independent free miners. Since the early Middle Ages the Derbyshire miners had exercised the right to dig for lead ore on any land regardless of ownership save only for churchyards and roads within a fairly undefined area known as the "King's Field". So long as the mining of lead had remained a relatively small-scale business serving a localized market, these rights had gone mostly unchallenged by the landowners and lords of manors within the orefield. The King's Field in the sixteenth century covered land which lay within the Crown's Duchy of Lancaster, and it was this body which claimed the right of appointment over the overseer of the mining industry, the Barmaster. This post was usually rented to a local gentleman or aristocrat by the Crown, though the miners had long argued for the election of the Barmaster from among their own ranks. In return for maintaining the mining laws of the King's Field, and appointing under-Barmasters from amongst the miners, the Barmaster claimed a duty known as "lot" upon the miners' produce of one thirteenth of their ore, and "cope", a tax of four or six pence per load of ore bought by merchants. The Barmaster was also required to appoint a court of twenty-four miners to ensure the implementation of mining law, known as the Barmote. These courts often enjoyed extensive freedom of action and were popular with the miners, who regarded them as the source of their peculiar liberties, resenting any incroachment by equity or common law upon the jurisdiction of the Barmote.

These unusual liberties operated in favour of the independent free miners who generally made up the juries of the Barmote courts. In essence, the mining laws were egalitarian and democratic. The ideal role of the Barmaster, miners explained, was to ensure that "noe man had more power than an other"," to "doe right to them that be opprest". ${ }^{18}$ Clearly such laws and institutions favoured the small producer and had been designed for a period when geological and social conditions had allowed such workers to control the industry.

The right of free mining originated at some time prior to the Norman Conquest, and the liberties granted thereby were seen by early modern

\footnotetext{
is PRO E101280/18.

"For two exceptions see BL Add. Mss. 64908 fo. 134; PRO DLA/103/18.

"Sharp France, "Thicvelcy Lead Mines", p. 94.

" E. Manlove, "Customs of the Lead Mines", 1653, repr. W. W. Skeat (ed.), Reprinted Glossaries 1873, p. 16.
} 
commentators to stand in contradiction to the logic of Norman manorialism. ${ }^{19}$ It is likely that the Barmote laws merely formalized and codified a form of production which had been in operation for generations on the open moors. The Derbyshire mining laws had their parallels with those operative in Cornwall and the Forest of Dean, where the right of free mining was also strong. In all of these mining communities conflict occurred over the extent and nature of the "libertie of free searching" throughout the course of the early modern period. ${ }^{20}$ This conflict was intensified by the profits to be made from the expansion of ore mining as wealthy entrepreneurs attempted to "rationalize" or marginalize ancient customs which were perceived as barriers to economic growth. ${ }^{21}$

In the late sixteenth and early seventeenth centuries the Derbyshire lead industry was revolutionized as a consequence of three related events: the collapse of Continental lead mining, the introduction of the cheaper and vastly more productive ore hearth smelting mill in place of primitive "bole" smelting techniques, and innovations in mining technology allowing the exploitation of deeper veins. ${ }^{2}$ Both the smelting mills and the opening up of major underground works with ventilation shafts, together with soughs and engines for draining inundated deposits required capital investment beyond the means of the free miners. ${ }^{23}$ Attracted by the rising price and burgeoning international market for lead, the local aristocracy and lead merchants began to expand their hitherto limited commitment to the extraction and smelting of lead.

The early seventeenth century witnessed a vast increase in the population of the High Peak mining field as poverty-stricken labourers were attracted into the area by the employment opportunities afforded by a revitalized mining industry. Population, poverty and industry all coincided within lead mining townships. This was a social reality quite apparent to contemporaries. One JP's return in the hungry year of 1631 made reference to "those parishes where the poore are set on by the lead mynes whereof our Hundred of High Peak hath much imployment and almost all set on work by them." ${ }^{24}$ Elite observers expressed concern over the supply of food to the industrial north of the county, in which some 60 per cent of Derbyshire's population was concentrated by $1638 . .^{25}$ If the 1664

19. Daniel "The Origin of the Barmote Court System: A New Theory", BPDMHS, 8/3 (1982); SRO Bag.C.550; BL Add. Mss. 6681 fos. 189-191, 201-205.

${ }^{20} \mathrm{~B}$. Sharp, In Contempt of All Authority: Rural Artisans and Riot in the West of England, 1586-1660 (Berkeley, 1980), pp. 190-219; A. K. Hamilton Jenkin, The Cornish Miner: An Account of his Life Above and Underground from Early Times (London, 1927; $1962 \mathrm{edn}$.), pp. 122-170; "Western Circuit Assize Orders 1629-48", Camden Society, 4th Ser. 17, pp. 52-53.

21 Sec, for example, the comments made on mining law in SRO Bag.C.3438.

22 Kicman, Lead Industry, pp. 40-85, 164-191.

25 BL Add. Mss. 6686 fos. 114-116; Sharp France, "Thicveley Lead Mines", pp. 15, 19; PRO C2/Jas I/M13/61; E134/4 Chas I/Mich 33.

24 PRO SP16/193/29. 25 PRO SP16/405/Pt. 2. 
Hearth Tax exemption rates can be relied upon, the lead ore fields of the High Peak and Wirksworth and the Hundred of Scarsdale in which coal and iron mining, as well as lead smelting, were important employers experienced deep levels of poverty. The development of the lead industry stimulated economic growth outside the bounds of the orefield, creating employment opportunities in transport, marketing and the processing of lead, as well as providing a spur to the commercialization of food production for the industrial north ${ }^{26}$ The expansion of the lead mining industry attracted large numbers of landless proletarians into the orefield, altering the social structure of the area. These "hirelings" or "cavers" were held in contempt by the free miners, who resented their incroachment on the miners' domain, their willingness to work as waged labourers for lords and entrepreneurs, and their apparent propensity towards criminal activity. ${ }^{27}$

The individual case of the townships of Great and Little Hucklow in the High Peak best illustrates the seismic changes which occurred in the social structures of many settlements of north-west Derbyshire in the years between 1580 and 1680 . In the middle of the sixteenth century the townships of Hucklow consisted of a collection of scattered hamlets of agricultural workers surrounded by open fields and separated by barren moorland; in 1563 Hucklow was amongst the most underpopulated areas of Derbyshire. ${ }^{28}$ It was not until 1578 that mining by workers claiming the right of free mining would begin in the area..$^{29}$ Output of ore appears to have been slight at first, but by 1613 was important enough for the manorial lords to attempt to restrict the miners' access to the lead deposits, resulting in Star Chamber prosecutions and litigation at the Court of the Duchy of Lancaster. ${ }^{30} \mathrm{By} 1641$ Hucklow's population had risen to around 600,61 per cent of whom were dependent upon the mines for their existence. Of these workers, about half were waged labourers or "cavers". By 1664 Hucklow lay in one of the most densely populated areas of the county; when the Hearth Tax assessors visited that year they found that 74 per cent of Little Hucklow's population were too poor to contribute to the tax, and a total of 84 per cent of Great Hucklow's households were in a similarly reduced state. ${ }^{32}$ By the 1680 s Hucklow's mining industry was dominated by the large workings of Hucklow Edge, worked twenty-four hours a day by shifts of waged labourers under the supervision of paid

${ }^{26}$ D. G. Edwards (cd.), Derbyshire Hearth Tax Assessments, Derbyshire Record Socicty, 7 (1982); SRO BM 80; J. Thirsk (cd.), The Agrarian History of England and Wales Vol.V.i. 1640-1750 Regional Farming Systems (Cambridge, 1984), ch. 5.

${ }^{27}$ Manlove, "Customs", p. 16; T. Houghton, Rara Avis in Terris, or the Compleat Miner (1681).

23 P. Riden, "The Population of Derbyshire in 1563", DAJ, 98 (1978).

PRO DLA/62/19.

30 PRO STAC8/226/27; PRO DLA/62/19; PRO DL5/27 fos. 183, 196, 485-486, 674, 1019 1020; PRO DL5/28 fos. 47, 58-59.

"PRO E101/280/18; PRO SP16/405 Pt. 2.

3 Edwards, Hearh Tax Assessments. 
clerks. In one year the mine produced 1,440 loads of ore, almost half the total output of the orefield estimated for the year $1541 .{ }^{33}$ Over the years between 1580 and 1680 Hucklow had been transformed from a collection of underpopulated villages surrounded by uncultivated wastes in a remote and inaccessible part of north-west England into a heavily populated industrial community producing raw materials for an international market. Attendant upon this process was the radical alteration of the lives of Hucklow's inhabitants. When mining began in the area in 1578 it was carried out by independent miners attracted into the area and indigenous smallholders turning to mining as a supplement to their incomes. A century later these men had been replaced by landless proletarians ${ }^{34}$ dependent upon a mining industry controlled by the rich merchants, aristocrats and gentlemen who owned mines like Hucklow Edge. With the vast increase in production of ore came both large profits to the shareholders of capitalized mineworkings and the exploitation of the workforce in those mines. Hucklow's experience in these years was by no means atypical.

Overall, the High Peak was noticeably more top heavy with poor, and the process of proletarianization more advanced than in the Wapentake of Wirksworth. In the neighbouring townships around Hucklow, more than half of the mining community were described in 1641 as "hirelings and cavers", compared with a mere 7 per cent of the mining workforce of Wirksworth town. Hearth Tax exemption rates were also markedly higher in the northern mining townships. ${ }^{35}$ In many High Peak townships miners were distinguished by their poverty and landlessness. Of the twenty-one freeholders in the township of Bradwell in the Peak in 1650, only two can be identified as miners. ${ }^{36}$ In the same year a survey of Wirksworth lists thirty-five owners of freehold land of whom eleven were miners, and a further ten enjoyed some other form of association with the industry. ${ }^{37}$

One explanation for this curious disparity in the experiences of settlements dependent upon the same industry and located within twenty miles of one another is to be found in the different structures of class and power prevalent in the northern mining villages and those in Wirksworth town.

Whereas the High Peak was dominated by two aristocratic families, the Cavendishes, Earls of Devonshire and the Manners, Earls of Rutland, Wirksworth was essentially a community of small producers. The manorial rights were held by the distant Duchy of Lancaster, which rarely interfered directly in the lives of the inhabitants, and granted them extensive freedoms and rights of common. By the 1620 s administration of the Duchy manor of Wirksworth had become so lax that distinctions of copyhold and

3 SRO Bag.C.549(3); Kicrnan, Lead Industry, p. 14.

34 J. P. Carr, "Open-Field Agriculture in Mid-Derbyshire", DAJ, 83 (1963), p. 71.

35 PRO E101/280/18.

* PRO E101/280/18; PRO E317/9/12.

"PRO E101/280/18; PRO E317/9/28; DRO D258/60/11; DRO D258/58/24c; DRO D258/28/20a, $c$ and d. 
freehold land had become hopelessly confused. ${ }^{38}$ Most land was held by yeomen or lesser gentry who either worked in or financed the mines; on the whole, the free miners of Wirksworth appear to have been more likely to have held land than other inhabitants of the town.$^{39}$ Relations between the yeomen miners and the lesser gentry of Wirksworth appear to have been relatively harmonious. Minor gentlemen such as John and Anthony Fearne shared the miners' outrage at the attempts made by greater gentry and the aristocracy at the limitation of the miners' rights, and were prepared to depose to that effect in court actions. ${ }^{40}$ Together with wealthier yeomen miners, such men formed the articulate leadership of the miners' defence of their rights when in the 1630s the Crown began to interfere with the "libertie of free searching" in the town."

The right of free mining in Wirksworth originated not only from custom and common useage, but was legitimated by Act of Parliament in 1554, an "indubitable custom strengthened by law" as the miners described their right in $1649 . .^{2}$ The relative health of the right of free mining in Wirksworth town is demonstrated by the ore production records of the area which indicate that as late as the middle of the seventeenth century the majority of ore was being produced from small-scale workings. ${ }^{43}$ The local lesser gentry and wealthier free miners dominated the government of both the mining industry and of Wirksworth town, holding office as underBarmasters, Barmote and court leet jurors, and parish officers. ${ }^{44}$ The free miners of Wirksworth were not merely integrated into the local community, they were an active part of it, capable of successfully defending their interests through the Barmote, and their social and financial links with the local gentry.

It is significant that out of eleven attempts by aristocrats and major landowners within Wirksworth Wapentake to remove their land from the King's Field between 1622 and 1662, only one was ultimately successful. The miners of Wirksworth were able to defend their traditional rights with far greater success than their counterparts in the High Peak not only because of their integration into the local community, but also because of their greater political and economic independence.

If this independence of manorial control was for Wirksworth miners an

3 PRO DLS/28 fos. 378-80.

9 PRO E317/9/28; PRO E101/280/18; PRO DL5/28 fos. 378/380; DRO D258/X/7c-c; DRO D258/58/20a-c. I hope to publish a fuller study of Wirksworth's mining community in the future.

* PRO DLAT2/31.

"DRO D258/56/52i; DRO D258/28/20r. For a brief account of the Dovegang dispute of the carly 1630 see Dias, "Lcad, Socicty and Politics", pp. 48-51.

2 BL Add. Mss. 6677 fo. 49.

"3 DRO D258/60/11.

4 DRO D258/28/20a-d; DRO D258/58/18i; DRO D258/58/24a-d; PRO DL4/105/1661/22; PRO DL4/106/1; PRO DL30/559/1; PRO DL30/54/666-676; PRO DL44/1121; G. Stcer, Compleat Mineral Laws of Derbyshire (1734), pp. 80-81. 
actuality, it also provided a model for the High Peak miners in their attempts to establish a right of free mining. One miner argued that "he veryley thinketh that ... [the miners] hath or ought to have the same right [ . . ] ] or lyke orders \& observacions for the ordering \& governinge of the myners and lead mynes within the Hundred of High Peak [ . . ] as for the Wapentake of Wirksworth."45 The aristocrats and upper gentry who owned and controlled most of the High Peak manors were unlikely to agree with these sentiments. Their attitude to the rapidly growing mining industry was double-edged. On the one hand, the free mining of lead was clearly a source of social disturbance, distrupting the hierarchic relationship assumed to exist between lord and tenant with new patterns of employment, leisure and labour relations. The swift profits which could accrue to the luckier free miners were resented by their social betters, who criticized the miners' supposed idleness, "unthryftiness" and "idle and lavish expenses". ${ }^{46}$ On the other hand, it was swiftly recognized by magnates like the Cavendishes, Manners and Eyres that the new mining industry offered the possibility of vastly increasing their already prodigious wealth. In both cases, the unusual mining laws of Derbyshire represented a block to the interests of landowners and entrepreneurs alike.

The laws and institutions of the King's Field granted unique freedoms and opportunities to men of comparatively low rank, helping to form a self-confident and assertive mentality, and a certain economic independence amongst the free miners at odds with the conventional values and life style expected of them by the assumptions of the élite. The King's Field laws maintained a legal framework in which small producers could prosper, and were regarded by many landowners "a strange custome, and sure inconsistent with property"."

The solution in the eyes of many landowners was therefore perceived to lie in attempting to limit or even abolish the mining laws which had created this unpalatable situation. Between 1608 and 1658, thirty-three manors in the High Peak lost the right of free mining through court action at equity or common law. In many cases following the removal of the right of free mining, manorial lords employed waged labourers to dig in the mines they had seized from the free miners, or compelled the miners to sell their ore directly to the lord's smelting mills at prices well below those obtaining on the open market. ${ }^{48}$ Exploitation of the rights of lot and cope on manors removed from the King's Field was often more vigorous and the duties required frequently higher than within the King's Field. ${ }^{49}$ Money

4 PRO DL4/64/11.

46 PRO E134/13 Jas I/Mich 3.

4 BL Add. Mss. 6677 fos. 50-51; BL Add. Mss. 6682 fo. 33; The Moderate Intelligencer, 30 August - 16 September 1649, BL E.572(6); SRO Bag.C.3438.

4s PRO DL1/323, unlisted Crown vs. Manners; PRO DL1/293 unlisted Crown vs. Sir Fras. Foljamb; PRO DLA/75/10; PRO DL4/120/1678/1; BL Add. Mss. 6677 fo. 51.

* BL Add. Mss. 6682 fos. 87-89; PRO STAC8/201/19; PRO DL1/323, unlisted Crown vs. Manners; PRO DLA/72/31; SRO PhC 335i. 
was also invested in the leases of tithe, tax and manorial rights from the Crown and the Duchy of Lancaster; the lead merchant and smelting family of Hassop, the Eyres, built their business empire upon their rent of the lot and cope rights for the King's Field in the High Peak. The possession of the lot and cope rights brought with it the office of Barmaster, which the Eyres unashamedly manipulated to squeeze out miners on their own and the neighbouring Manners estates. ${ }^{50}$

The miners were faced with heightened technological difficulties in their search for ore. As surface deposits were exhausted, deep mines were opened up which required capital investment beyond the means of the free miner. ${ }^{31}$ In consequence, many miners were either reduced to the status of day labourers or.were forced to rely upon the local gentry and merchants for loans of cash. In return, it was common for miners to mortgage their mine shares or smallholdings to these wealthier men. ${ }^{52}$ The passage of such shares and land into the hands of individuals such as Thomas Eyre caused further conflict and resentment between the miners and their betters. ${ }^{53}$

The presence of large numbers of landless poor in the High Peak mining villages created a cheap labour force which could be utilized by aristocrats and gentlemen investing in mining enterprises. These "hirelings" were not merely prepared to work for wages in other men's mines; they were also willing to work for lower wages than the free miner who had hit on hard times and needed temporary employment. ${ }^{34}$ On a number of occasions, waged labourers and "hirelings" led by their employers or manorial lords forcibly ejected free miners from their workings.

The opponents of the right of free mining in the High Peak were consequently aided in their project by the lack of integration of the miners into the community, the relative poverty of many of these men, and the internal divisions amongst those employed in the industry. The chief weapon in the fight against the miners' traditional rights was the legal system, backed on occasion by the armed force of the state.

Barmote law was essentially an informal set of oral rules designed for the self-government of an industry dominated by small producers. The rise of capitalist relations of production in the Derbyshire lead mining industry was not the consequence of the development of superior productive forces and organization over the outmoded work practices of an obsolete social group. There was nothing inevitable in the decline of the free

\footnotetext{
so See R. Meredith, “The Eyres of Hassop 147-1640", DAJ, 84 (1964) and 85 (1965); PRO DL1/366 unlisted complaint of William Goodwin; PRO DL1/323 unlisted Crown vs. Manners.

"Kieman, Lead Industry, pp. 13-14.

${ }_{52}$ PRO E134/2 Jas II/Mich 21; PRO C2/Jas I/Mich 13/61; PRO DLA72/31; DRO D258/42/15, unlisted receipt; DRO D258/47/7a.

s3 Meredith, "Eyres of Hassop", pp. 42-43.

4 PRO DLA1/17/19; PRO E134/13 Jas I/Mich 3; BL Add. Mss. 6685 fo. 56.

9s PRO DL1/323, unlisted Crown vs. Manners; PRO DL1/298, unlisted Crown vs. Lady Grace Manners; PRO DLA/75/10; PRO STAC9/1/13.
} 
miner any more than that social group greeted the evidence of this decline with passive resignation. Capitalism in north-west Derbyshire had its origins in the acts of ideological, legal and physical coercion carried out at the behest of a coalition of aristocrats, gentlemen and merchants throughout the whole of the seventeenth century. This process was uneven in its success and encountered resistance throughout; more than anything else the struggle for the mining industry manifested itself as an ideological battle over the law. Jurisdictional conflicts between the miners' Barmote and equity and common law expressed a wider struggle of differing concepts of property, legality and the social order itself.

Despite increasing interference from lessees of lot and cope rights, Barmote law tended to favour the interests of the free miner, institutionalizing and legitimizing their traditions and rights to an extent quite unique in early modern English extractive industries. Through membership of juries and tenure as deputy Barmasters many miners acquired an extensive knowledge of mining law, history and tradition. ${ }^{56}$ Since Barmote law relied on precedent and common usage older miners would be called before it to give evidence, often with a striking degree of accuracy, of events forty or fifty years in the past. ${ }^{57}$ The significance placed upon oral testimony and precedent in mineral cases reinforced the miners' sense of their own history and identity as a separate interest group in north-west Derbyshire, enjoying both specific rights and the general "libertie of free searching". Old miners made reference to their role in payment strikes against tithes in the 1570s in justification of their sons' and grandsons' refusal of the tithe between 1614 and $1634 .^{58}$ Barmote jurors were often significant in organizing this resistance, passing on the memory of these struggles through their oral testimony to courts and in Barmote meetings. ${ }^{59}$ This popular historical consciousness served to reinforce both knowledge of the law and of the efficacy of earlier resistance. Deponents called upon in George II's reign during court action aimed at proving the vicar of Hathersege's claim to a one-tenth tithe of the miners' production referred back to the failure of earlier attempts at collecting the tithe during the seventeenth century in justification of the miners' case. ${ }^{60}$ The Derbyshire miners of the mid-seventeenth century appear to have lived in a culture which was essentially oral. Taken as a whole, north-west Derbyshire's male literacy falls well below that of the national average for 1642; the miners were distinguished within their communities by the far greater likelihood of their being unable to sign their name. ${ }^{6 t}$ This oral culture was reinforced by the traditions of Barmote law. Sales of mine shares were transacted by

s6 PRO E134/13 Jas I/Mich 3; PRO DLA/66/6.

57 PRO E134/4\&5 Wm \& Mar/Hil 15; PRO DLA/98/34; PRO STAC8/219/4.

s8 PRO E/134/13 Jas I/Mich 3; PRO E134/8 Chas I/Mich 26.

99 PRO E134/13 Jas I/Mich 3; PRO E134/17 Chas I/Mich 4; DRO D258/42/15, unlisted mss. related to tithe cases.

co PRO E134/6 Gco II/Mich 4.

"D. Cressy, Literacy and the Social Order: Reading and Writing in Tudor and Stuart England (Cambridge, 1980), p. 73; PRO E101/280/18; HLRO MP 26 February 1642; DRO D258/60/6. 
word of mouth in public; because of its oral nature, mining law was popularly believed to have originated with the Druids. ${ }^{62}$ Miners often committed to memory the entirety of mining law, together with extensive precedent, frequently in spite of illiteracy. ${ }^{63}$

This stood in contrast to the type of law practised in the Westminster equity courts to which gentry opponents of the miners' liberties took their cases. Litigation here was expensive, and the emphasis lay upon written documentation and formal definitions of property. Westminster attorneys experienced difficulties in appreciating the nature of Barmote law, regarding the right of free mining as a dangerously communistic "levelling custom". "The usefulness of oral evidence was increasingly coming under attack during the period; in 1726 Sir John Statham referred to the miners' customs as "all pompous pretence". He argued that since Barmote courts were not courts of record, "no record or footsteps remain" proving property or custom "other than what occurs to everyone's memory". Sir John was reiterating earlier arguments against the miners' right to selfgovernment that since Barmote custom consisted merely of "presentments of the miners themselves [ . . . they] cannot prejudice much less conclude others rights". ${ }^{.5}$ What was occurring was as much a clash of oral and literate cultures, of formal and informal systems, and of private and communal notions of property, as of contending jurisdictions.

The miners considered Barmote law to be so important that "too break this custome is to break some part of the sinews of the Kingdome", without which mining would be reduced to "a new form of disorderly useage".66 Around it they defined their rights and the origin of their independence. Within the Barmote miners occasionally organized resistance to the latest impositions of their betters. For decades the High Peak miners prevented the collection of the lead tithe, organizing themselves during Barmote meetings where speeches were made, propaganda disseminated, money collected for legal action and "illegal combinations" formed. ${ }^{67}$ In contrast, landowners sought to undermine both the Barmote and the right of free mining through litigation elsewhere, in equity or common law courts. Since many manorial lords were also Justices of the Peace, they could arrest miners for trespass or "riotous invasion" of their land; the miners protested that they were merely exercising their right of free mining ${ }^{68}$ Inher-

62 SRO Bag.C.549(3); SRO Bag.C.550; BL Add. Mss. 6668 fos. 506-507; BL Add. Mss. 6681 fos. 189-191, 201-205.

ss See case of William Booth, PRO DLAח2/31.

4 Treby's Mss. Reports, 22-24 Chas II, Middle Temple Library. I am indebted to Dr Alan Cromartic for this reference.

as BL Add. Mss. 6677 fo. 51; L. Wyllies, "The Working of the Derbyshire Lead Mining Customs in the Eighteenth and Ninctecnth Centuries", BPDMHS, 10/3 (1988), p. 152.

* BL Add. Mss. 6686 fo. 62; PRO DL5/29 fos. 432-433.

" BL Add. Mss. 6681 fos. 360-371; PRO E134/17 Chas I/Mich 4; PRO E134/13 Jas I/Mich 3; PRO E134/4 Chas I/Mich 33; PRO E134/8 Chas 1/Mich 26.

4 DRO QSB/103; DRO DL1/366, unlisted complaint of William Goodwin; PRO DL1/293, 
ent in these developments was a move away from the underlying assumptions on which Barmote law was founded: that the prosperity which came from the mining of lead was there for all to share, and that any conflicts arising from the extraction of ore could be solved in a consensual framework. The free miners who found the Westminster courts "terrifying", 69 and those who criticized the gentry monopoly of power and office ${ }^{70}$ understood the significance of the jurisdictional shift away from the Barmote court all too well.

The miners responded to these limitations on their rights and offices with their own court prosecutions and, where these failed, often violent crowd action. Miners initiated at least seventeen riots as a result of their frustration at the removal of the right of free mining between 1608 and 1658. These disturbances reached their height during the period of the English Revolution when on seven separate occasions between 1641 and 1658 armed bands of miners up to 200 strong confronted mounted gentlemen and their retainers led by the Earl of Rutland on his Haddon estate. ${ }^{7 n}$ The local elite were scarcely powerless in the face of this threat. Militia forces were ordered to suppress crowds of 300 to 400 miners at Litton in $1634 ;^{2}$ the king himself intervened to order a stop to rioting at Dovegang near Wirksworth in $1632 ;^{73}$ troops were sent to Dovegang in 1653 by the Council of State after rioting left a man dead, ${ }^{74}$ four years after the same regiment had been ordered to suppress rioting miners invading the Earl of Rutland's estates yet again. ${ }^{75}$ The Earl's father, Sir George Manners, may have unconsciously revealed a general attitude amongst his gentry neighbours when he prayed for better entertainment "than alwaies to live a poor base Justice, recreatinge myself in sending rogues to the gallowes". ${ }^{76}$ Certainly the High Peak miners had reason to regard the Manners family as their "implacable enemy". It was the Manners of Haddon who had physically and legally crushed the right of free mining in Hazelbadge in 1630, Harthill in 1641 and Netherhaddon between 1648 and 1658. They had earlier attempted to do likewise in Aldwark and Cole Eaton near Wirksworth in the 1620 s but had found the right of free mining harder to

Crown vs. Sir Fras. Foljamb; PRO DL4/124/1686/7; PRO DL1/323, unlisted Crown vs. John Manners.

- PRO DLA/90/24.

" PRO RGO 33 frontispicce.

7 DRO QSB/103; HLRO MP 19 June 1648; Journal of the House of Lords 1647-1648, pp. 335, 442, 595; Journal of the House of Commons 1648-1651, pp. 175, 242, 284, 298, 303; PRO SP18/26/93; PRO DL1/366, unlisted complaint of Rowland Furniss; PRO DL1/369, answer of Earl of Rutland; PRO DL1/379, answer of Lathom Woodruffe; N. Kirkham, "A Royal Mine in Nether Haddon?" DAJ (1955).

$n$ BL Add. Mss. 64908 fos. 128, 130-131.

3 BL Add. Mss. 6686 fo. 158; PRO DL5/31 fo. 201.

$"$ CSPD, pp. 222, 255-256.

7s CSPD, pp. 335, 337-338; Journal of the House of Commons 1648-1651, p. 303.

7 L. Stone, The Crisis of the Aristocracy 1558-1641 (Oxford, 1965), p. 391. 
disprove there than that to the north. Where attempts to prevent free mining proved successful, the Manners either forced the miners to sell their ore direct to their smelters, as at Haselbage where John Manners was buying ore at 9 shillings per load when the market price was 24 shillings, ${ }^{n}$ or ejected the miners all together and introduced waged labour. This was the case in Haddon after the final defeat of the miners, when the area's lead deposits were opened up using the newest technology available worked by "hirelings". ${ }^{78}$

The dispute between the Earl of Rutland and the High Peak miners witnessed the last, most protracted, and probably the most bitter, attempt to maintain the right of free mining through crowd action. Although the miners of Derbyshire remained a potential source of social disturbance in the eyes of their betters into the eighteenth century, rioting miners after 1658 seem to have been concerned with immediate issues, such as loss of employment, the price of bread, or forced impressment into the militia. ${ }^{79}$ Elite definitions of property and legality, having achieved an uneasy domination in the seventeenth century, remained unchallenged by the riots of eighteenth-century lead miners. The hegemony of the forces of capital in the lead industry, though never their absolute domination, had been established in the seventeenth century. An important element of this victory lay in events on the Earl of Rutland's estates during the years of the English Revolution.

The mining community had been divided by the outbreak of civil war in 1642, large numbers enlisting for both the king and for Parliament, ${ }^{80}$ while the Earl of Rutland vacated Haddon Hall for the duration of hostilities. He returned in 1647 to find that many of those miners whom he had ejected from his estates in 1641 had resumed mining operations there. ${ }^{81}$ Rutland's renewed attempts to prevent free mining on the fields around his ancestral home of Haddon Hall resulted in violent confrontations between his supporters, including many prominent local gentlemen, and large crowds of miners, ill-disposed to display the deference expected of them to such wealthy men. The mood of defiance amongst the miners was summed up by one member of a crowd who told the Earl's steward

that there was lead ore to be gotten there [in Haddonfields] and that they would work there whosoever said nay, and that they would bring thousands to assist them

7 PRO DL1/323, unlisted Crown vs. Manners; BL Add. Mss. 6682 fos. 87-89.

7 BL Add. Mss. 6686 fo. 148; BL Add. Mss. 6678 fos. 153-154; W. Recs, Industry before the Industrial Revolution, II (Cardiff, 1968), p. 654; PRO E134/23 Chas II/East 5; PRO DLA/124/1686/7.

" SRO Bag.C.704(1-15); SRO SpSt 60498 (21); SRO WHC 34; M. Thomas "The Rioting Crowd in Eightecnth-Century Derbyshire" DAJ, 95 (1975); G. G. Hopkinson, "Lead Mining in Eighteenth-Century Ashover", DAJ, 72 (1952); G. G. Hopkinson, "Lead Mining in the Eyam District in the Eightecnth Century", DAJ, 80 (1960).

BL Harl. Mss. 6833 fos. 58b, 59, 68.

"PRO DLS/34 fo. 300; HLRO MP, 20 February 1643. 
and [ . . . ] that they had nothing to loose and that they cared not for their carcasses and $[. .$.$] that if they were interrupted and those they looked for came unto$ them it was not working there [in the mines] should serve their turn, for they hoped to have the House meaning thereby the mansion house of [ . . . ] Hadden. ${ }^{82}$

Such riots resulted in prosecutions at the Quarter Sessions, Assizes, Court of King's Bench and ultimately the House of Lords, which committed eleven miners to Fleet prison in June 1648. This experience did not prove to have had a suitably salutary effect on the miners, for by late 1649 , after having invaded Haddonfields twice more, and been frustrated in their attempts to secure the support of the House of Commons, they took their resistance to the Earl of Rutland, the House of Lords and now the state itself several steps further by declaring their support for the radical Leveller Agreement of the People. ${ }^{83}$ The Council of State ensured that any insurrectionary threat the miners might pose was swiftly snuffed out with the despatch of Colonel Sanders' regiment to the area, and the Colonel's imposition as Barmaster. Further disturbances followed in the late 1650s, but with the Restoration came the end of the affair, as the boundaries of the King's Field were permanently set outside the Manners estates, making Haddonfields safe for the large-scale capitalist exploitation of its minerals. ${ }^{\text {st }}$

It is evident from the miners' frequent recourse to crowd action throughout the first half of the seventeenth century that they were prepared to defend their rights by force. But what occurred at Haddonfields between 1641 and 1658 differed in both form and content from earlier miners' disturbances. The state, in the form of both Houses of Parliament, the army, the Council of State and both the criminal and equity law courts, intervened directly on the side of the Earl of Rutland. The miners' resistance to their rulers will was both more extensive and sustained than in the past. Miners hauled before the House of Lords to answer for their riotous invasions of Rutland's estate, simply refused "to submitt to this House or to acknowledge theire offence". ${ }^{85}$ Large crowds were mobilized to march out into Haddonfields against the Earl's men in both 1648 and 1658; ${ }^{86}$ very often those miners who were named in court prosecutions had been responsible for earlier trouble either on the Earl's land or elsewhere. Anthony Sellars of Taddington had been the key leader in organizing the

2 HLRO MP, 19 Junc 1648, affidavit of Thos. Needham.

w The Moderate, 59, 21-28 August 1649, BL E.572(1); The Moderate, 61, 4-11 September 1649, BL E.573(7); Mercurius Elencticus, 25 June-2 July 1649, BL E.562(18); Mercurius Pragmaticus Pt. 2 No. 11, 26 June-3 July 1649 BL E.562(21); The Kingdomes Scout, 3124 31 August 1649 BL E.532(30); The Case of a Publique Business / . . J DCL; BL Add. Mss. 6677 fo. 49; A Modest Narrative, 25 August - 1 September 1649.

* O. R. F. Davics, "The Dukes of Devonshire, Neweastle and Rutland 1688-1714: A Study in Wealth and Political Influence", unpub. D.Phil. (Oxford, 1971), pp. 188-189.

is HLRO MP, 16 August 1648.

" HLRO MP, 19 June 1648; Kirkham "Royal Mine", pp. 27-28. 
non-payment of the lead tithe in that area in 1642; he had been a member of Peak Forest Barmote in 1640 together with other tithe resisters. In 1648 he had been amongst those miners imprisoned by the House of Lords for their part in leading riots on Rutland's land, and in 1658 was prosecuted at the Quarter Sessions by the Earl for further rioting in Haddonfields. ${ }^{87}$ Jonas Crosgill had been another miner who had refused to submit to the House of Lords' authority and had been placed in Fleet jail for his leadership of the 1648 riots; he was further prosecuted by Rutland at the court of King's Bench the following year and was once again in trouble in 1658 for riot in Haddonfields. ${ }^{88}$ Also named in the 1649 King's Bench action as a leader of the miners was William Heaward, a free miner who had probably served as a parliamentary soldier in the wars. Heaward's name was attached to the petition sent to the House of Commons later that year which was printed in the Leveller newspaper, The Moderate. ${ }^{89}$

Like many other men of the middle order who had been active for Parliament during the Civil War, Heaward was disappointed at the actions of the House of Commons. Perhaps more than anything else, it was this sense of disillusionment that drew such individuals to the Leveller movement. Certainly some of the rhetoric deployed in the miners' petition to Parliament in 1649 is reminiscent of the language of Overton or Lilburne, or the bitter retort of Edward Sexby at Putney in 1647: "We have engaged in this kingdom and ventured our lives, and it was all for this: to recover our birthrights and priviliges as Englishmen and [yet] by the argument urged there is none [ . . . I I wonder we were so much deceived." on the aspirations, frustrations and labour traditions of artisanal small producers such as the free miners as much as on complex theories of popular sovereignty that the Leveller movement was based. The petition Heaward signed expresses this sense of disillusionment with the Commonwealth:

[the miners] did not doubt but by their appeal unto your Honours (who ought to be the Conservators of all the People's Customs and Immunities) to obtain not only speedy protection but also such relief against their adversaries as the justice of their cause [ . . ] should require $[\ldots]$ but so it is [ ...] to our great grief and amazement we find that Prerogative hath many Pro[te]ctors by whose power and policy Justice is either denied or delayed, the oppressors, because Rich and powerful cherished; and the oppressed, though many thousands, ready to perish for bread; because poor, altogether neglected, and not only so but more oppressed and absolutely exposed to the power of an implacable enemy who leaves no way unattempted to destroy them.

"Kirkham, "Royal Minc", p. 23; PRO E134/17 Chas 1/Mich 4; PRO E101/280/18; HLRO MP June 19 1648; SRO Bag.C.1413.

Journal of the House of Lords 1647-8, pp. 442, 595; PRO SP18/26/93; HLRO MP, 19 June 1648, affidavit of Jonas Crosgill.

* BL Adud. Mss. 6677 fo. 49; PRO SP28/128/15; PRO SP19/139 fo. 36; PRO E101/280/18.

A. A. P. Woodhouse, Puritanism and Liberty (London, 1938, $1986 \mathrm{cdn}$ ), p. 69. 
The hyperbole of the language should not blind us to the reality it described. The authors of the miners' petitions had an acute understanding of the structural power of their opponents, vested in "orders of the Lords House", the "suites and molestations of the Earl" which had caused them "utter ruine", , the control of lead prices by Rutland and others, which was "too great an oppression to a free-born people", and the tenure of the Earl and other "malignants" as leasees of lot and cope and Barmaster rights, who take "no care to uphold the laws and customs of the mines, but aym at their own private ends".

Such a critique was not simply the consequence of the English Revolution's politicization of many ordinary people. The Derbyshire lead miners, like other members of the "lower orders" of early modern England, possessed a distinct descriptive vocabulary for the inequalities of wealth and power they were witness to.

The miners understood that the equity and common law courts did not operate impartially, but rather existed for men like Sir Robert Heath or the Earl of Rutland to "terrifie [ . . . ] poor miners". ${ }^{93}$ Unlike their betters, the miners considered themselves to be an orderly and lawful group of men, proud of their self-government through the Barmote, and resentful of attempts at the restriction of its jurisdiction. ${ }^{24}$ Miners were angered at the breach of Barmote law enacted by the Attorney General, Sir Robert Heath; this fury was compounded by their inability to bring him to account. Heath's capacity to intimidate Barmote jurors undermined the whole basis of mining law and mirrored the disparity of power between the "poor myners" and the king's Attorney General. 95

Similarly, the possession of tithe and tax rights by gentlemen, aristocrats and priests, and the consistent and largely successful attacks on the right of free mining, provoked illuminating remarks from miners. Comment was passed upon the structural inequalities of north-west Derbyshire society. Enclosures of land and the removal of mining rights by the Earl of Shrewsbury in Longstone "much wronged" the tenants and miners, but they felt themselves unable to effect any "reforme in respect of the said Earl his greatness". 9 In Elton, miners fulminated against Sir Francis Foljamb, the lord of the manor, who "contrarie to all orders of the mines" instructed that the miners "by strong hand be driven out". his ilk, one local miner called William Toft observed, kept the mining rights of their manors to themselves "by reason of their great power \& commaunde in those parts and not by anie just title or property they had thereto". ${ }^{98}$ Toft's notion of legality may well have been informed by his

"BL Add. Mss. 6677 fo. 49.

2 The Case of a Publique Business I . . J DCL.

"3 PRO DLA/90/24.

PRO STAC8201/19; PRO STAC8/226/27; PRO DL41/17/19.

"s PRO DLA/91/16.

" PRO DLA $5 / 10$.

* PRO DLA71/36.

* PRO STAC9/1/13. 
period as an under-Barmaster. It is significant that when criticizing manorial lords, miners often accused them of "illegal impositions" as much as railed against their greater social power. Clearly a notion of legality operated in justification of the miners' actions. In any case, it was not a concept of legality shared by their betters; William Toft was to be indicted by the Duchy court for "evill words against the honour of this Court" in the course of his dispute with Foljamb, following the grant of mining rights in the manor of Elton to that gentleman. ${ }^{99}$

Toft was hardly alone in his opinions. When Sir Francis Needham sought to remove Steeple Cole Hills near Wirksworth from the free mining laws of the King's Field in 1623 he united the local lesser gentry and miners of that town in condemnation of his actions. Anthony Fearne argued that

hee did not ever hear of any yeoman, husbandman or other Ordinary persons keepe out the Kings Minors or stop them from searching or digging for lead oare in any of their grounds within the Wapentake of Wirksworth [ . . ] manie of them are greate men that doe stopp and keepe the mynors [from] digginge \& gettinge lead oare in their grounds [ . . . ] most of the said great men doe keepe the saide myners forth of the grounds rather for fear of [the great men's] greatness \& displeasure than by anie just tytle.

John Fearne agreed with this interpretation, pointing to the "terrour and feare" instilled in miners by the "men of greate commaunde [ ...] whereby poore men for want of supportacion are driven from their right". The lords of manors, Fearne argued, "beinge powerful men [have .... ] by violence holden the myners downe by their owne combination". ${ }^{100}$

This language was a reflection of the miners' economic and political circumstances as independent small producers threatened by wealthier and more powerful men than themselves. In so far as it recognized inherent structural antagonisms in the early modern English body politic, it can be considered a language of class. The miners were, as they had it, "oppressed" by indirect forms of exploitation levied upon them by "great men": tithes, taxes, the duties of lot and cope. The free miners, unlike the "hirelings", had little experience of direct exploitation in the form of waged labour. They engaged in such activity in the mid-seventeenth century only out of necessity for limited periods of time, or out of attraction for high piece rates where they continued to enjoy considerable control over their labour. ${ }^{101}$ As a consequence, the free miners' vocabulary addressed the unequal distribution of power in north-west Derbyshire society as articulated through aristocratic control of tithes, taxes, manorial rights and the law rather than any directly exploitative relationship between worker and employer. This was the language of the resentful small producer or artisan, whose control of life and livelihood was

PRO DL5/29 fo. 289. The Duchy court later reversed this decision.

${ }^{100}$ DLAT2331.

101 PRO E134/3 Jas II/East 15; DRO D258/4221. 
threatened by "men of great commaund", not that of an emergent working class. If a proletariat is to be found in the Derbyshire lead industry in the seventeenth century, it is amongst the "cavers" and "hirelings" so despised by the free miners. But from this disparate, marginal and illiterate mass there is only silence.

Many aspects of the mining industry of the early eighteenth century would have been unrecognizable to a free miner of one hundred years earlier. A revolution had occurred in the ownership, control and organization of extraction. In mines such as Odin in Castleton large gangs of miners worked as "copers" on different levels of a deep mine throughout the year in shifts. ${ }^{102}$ Even surface work was being systematized and mechanized to ensure the highest possible labour productivity. ${ }^{103}$

Nonetheless, the miners' struggles of the seventeenth century had not been wholly unsuccessful. The right of free mining had been protected in certain manors of the High Peak and within the Wapentake of Wirksworth, where independent production continued, albeit on a dramatically reduced scale. Within the big capitalized works the skilled face workers retained some of the labour traditions of their forebears. Underground "copers" worked for piece rates which bore certain similarities to the earlier share system. Face workers maintained considerable control over the conditions of their own labour, contracting into mines as groups. Management of underground "carriers" seems to have been the responsibility of these labour aristocrats of the mining industry. The piece rates they were able to command, partly in consequence of the continued possibility of self-employment as free miners within certain areas, were often very high. In the deep works of the Dovegang in the 1670s, the face workers won such high piece rates that the mine scarcely turned a profit. ${ }^{104}$

The social and economic changes of the seventeenth century created the conditions for industrial diversification in north-west Derbyshire in the eighteenth century. The establishment of a large proletarianized population in many townships during the seventeenth century which was particularly vulnerable to fluctuations in the international lead market necessitated the introduction of alternative sources of employment. The textile and hosiery trades, land reclamation schemes in the High Peak, and the construction of turnpike roads and canals all benefited from the increasing poverty of the free miners. ${ }^{105}$ When in 1771 Richard Arkwright established his cotton mill at Cromford, the presence of a large labour force already accustomed to working for long hours and low wages in an industrialized environment was doubtless amongst the factors which attracted him. He was not alone in this as during the late eighteenth century textile mills sprang up among villages whose main sources of employment had hitherto

100 Unlisted accounts of Odin mine, Chatsworth House; SRO OD 1495.

${ }^{103}$ SRO Bag.C.206(3).

104 PRO RGO 33.

10s Hopkinson, "Ashover", p. 5; DRO QAB/1/6/3; PRO DLA1/19/4; DRO 1038A/PO 261. 
been in the mines. Thus the growth of capitalist production relations in one industry conditioned similar developments in others.

If the industrial revolution of the late eighteenth century had its origins in the social and economic develoments of the previous century and a half, so the class consciousness of Derbyshire's industrial workers was not the spontaneous generation of the mill and the loom. The mining industry began its long decline in the last years of the eighteenth century, and many ex-miners migrated to the new industrial cities. But they took with them a language and mentality conditioned as much by the memory of lost liberties and independence as by the new realities of a wholly industrial age.

Despite the domination of large-scale capitalist enterprises, the independent political traditions of the free miner persisted. The miners, remarked a clergyman in 1800 , retained "a rudeness of character [and] a riotous disposition". They confirmed this verdict with their frequent crowd visits to Chesterfield market to set the price of corn in the years of dearth which marked the last years of the eighteenth century. Information reached the Privy Council in those years of the secret manufacture of lead bullets in Derbyshire, and of meetings of radicals in Castleton. ${ }^{106}$ The miners of Bradwall, jealously clinging to the custom of free mining as late as $1812,{ }^{107}$ were complaining in 1789 that the lead merchants were "abating the prices of ore" and "grinding the faces of the poor". They called a meeting at the Bull's Head tavern to discuss joint action; the same alehouse saw the first meeting of a miners' "Friendly Society" eight years later. ${ }^{108}$

The political culture of these last "free miners" of the eighteenth century was of a Janus-faced nature. It looked back to the preservation of still not wholly lost ancient liberties. It vigorously berated the present for the toleration of price-setting by wealthy merchants. ${ }^{109}$ And it looked forward to a new working-class tradition founded upon institutions such as the Friendly Society and the Jacobin influences which so terrified a Derbyshire gentleman writing in the troubled year of 1791 . He described in lurid terms the activities of Paineite radicals in Sheffield and worried over recent gatherings against the Duke of Rutland's enclosure of common land on Stanton moor, overlooking Haddonfield where 150 years before an earlier generation of rioters and radicals had confronted the Duke's ancestor. ${ }^{110}$

\footnotetext{
${ }^{100}$ Thomas, "Rioting Crowd", p. 44; R. Wells, Insurrection: The British Experience 17951803 (London, 1803), pp. 76, 222.

${ }^{107}$ Chatsworth House BC 214 Bradwcll ore measurements 1789-1800.

100 Rules for a Friendly Society of Miners at Eyam, 1797 DCL; SRO Bag.C.587(71).

109 MCL Carill Worslcy MSS M35/2/44/4, 8, 10, 44; SRO Bag.C.587(71).

110 MCL Carill Worslcy MSS M35/2/44/41.
} 
Abbreviations

BPDMHS Bulletin of the Peak District Mines Historical Society

BL

CSPD

$D A J$ British Library

Calendar of State Papers Domestic

DCL

Derbyshire Archaeological Journal

DRO

Derby Central Library (Local Studies Library)

HLRO MP

Derbyshire Record Office

$\mathrm{MCL}$

House of Lords Record Office Main Papers

Manchester Central Library

PRO

Public Record Office

SRO

Sheffield Record Office 


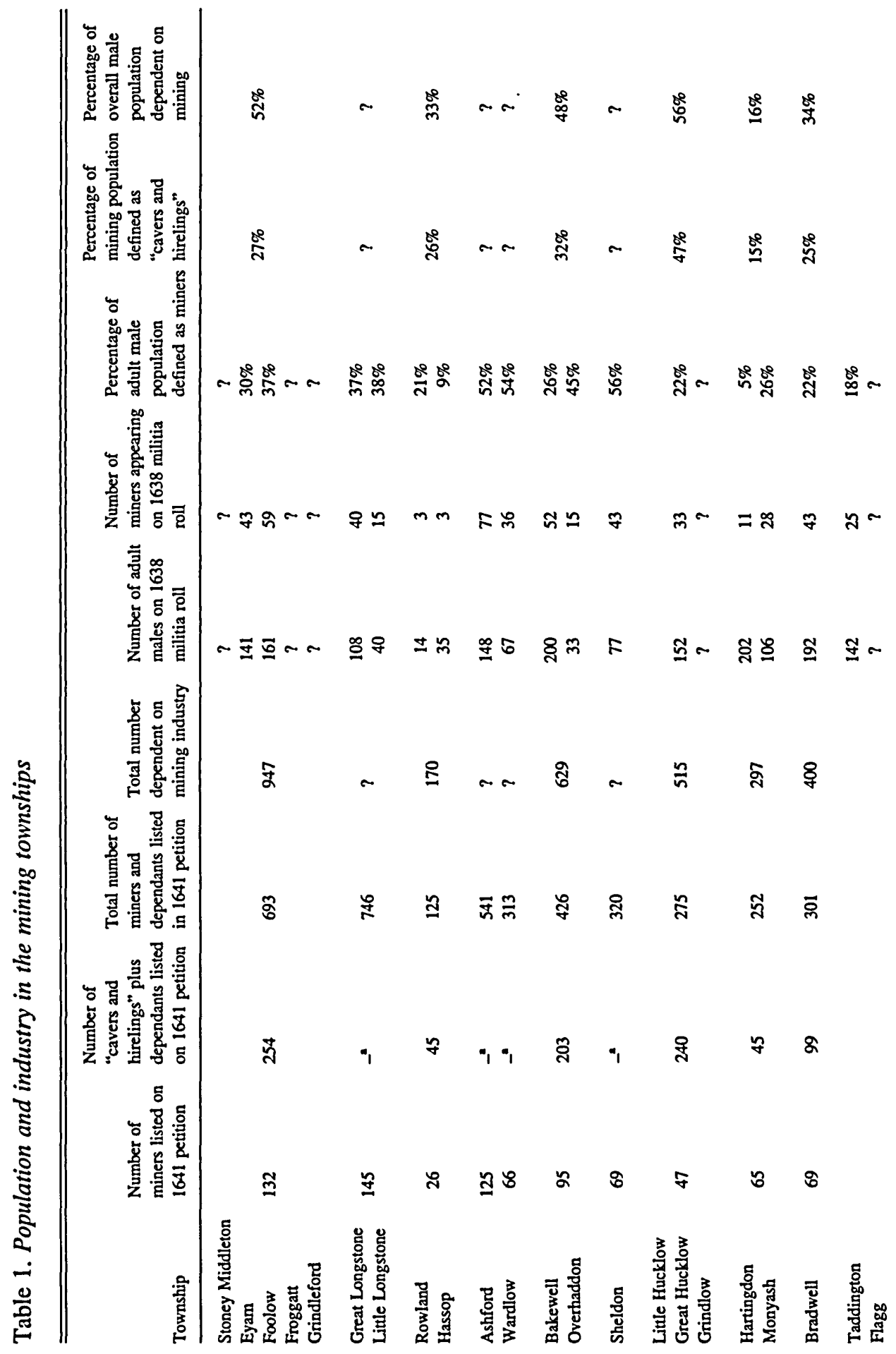




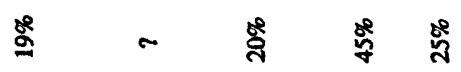
कू
\&

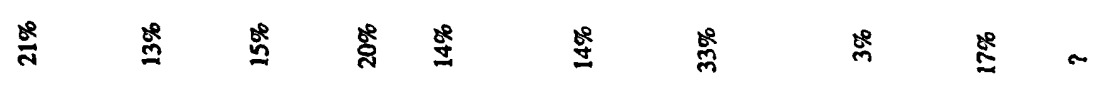

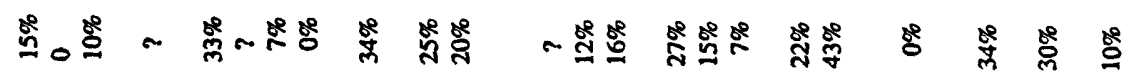

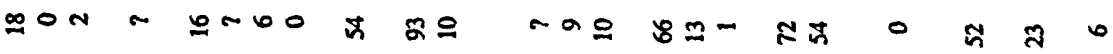

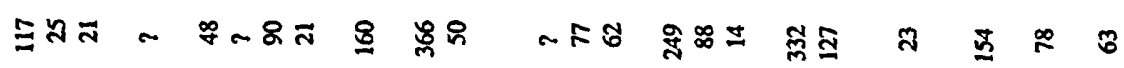

ำ

ఫั ฐ ส

6 \&

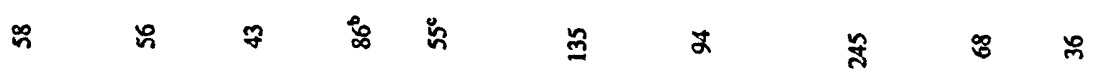

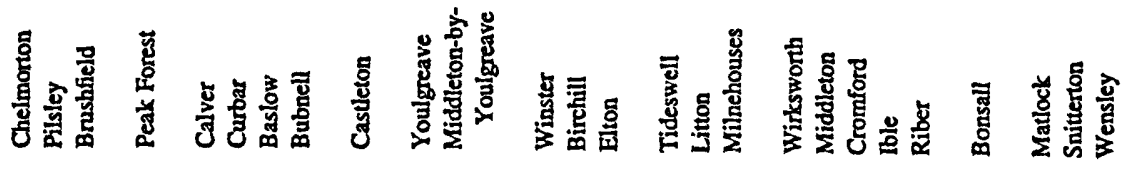




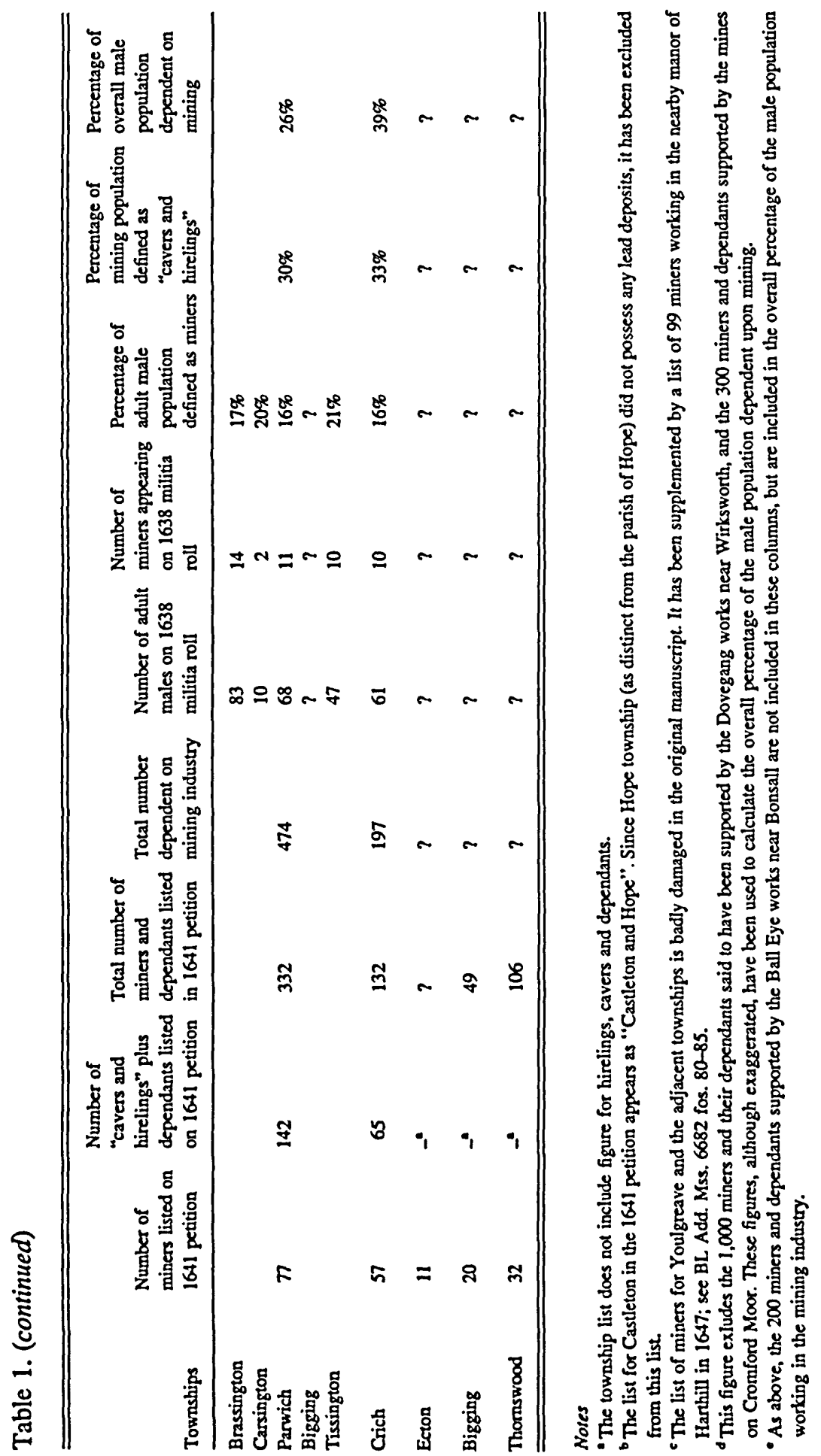




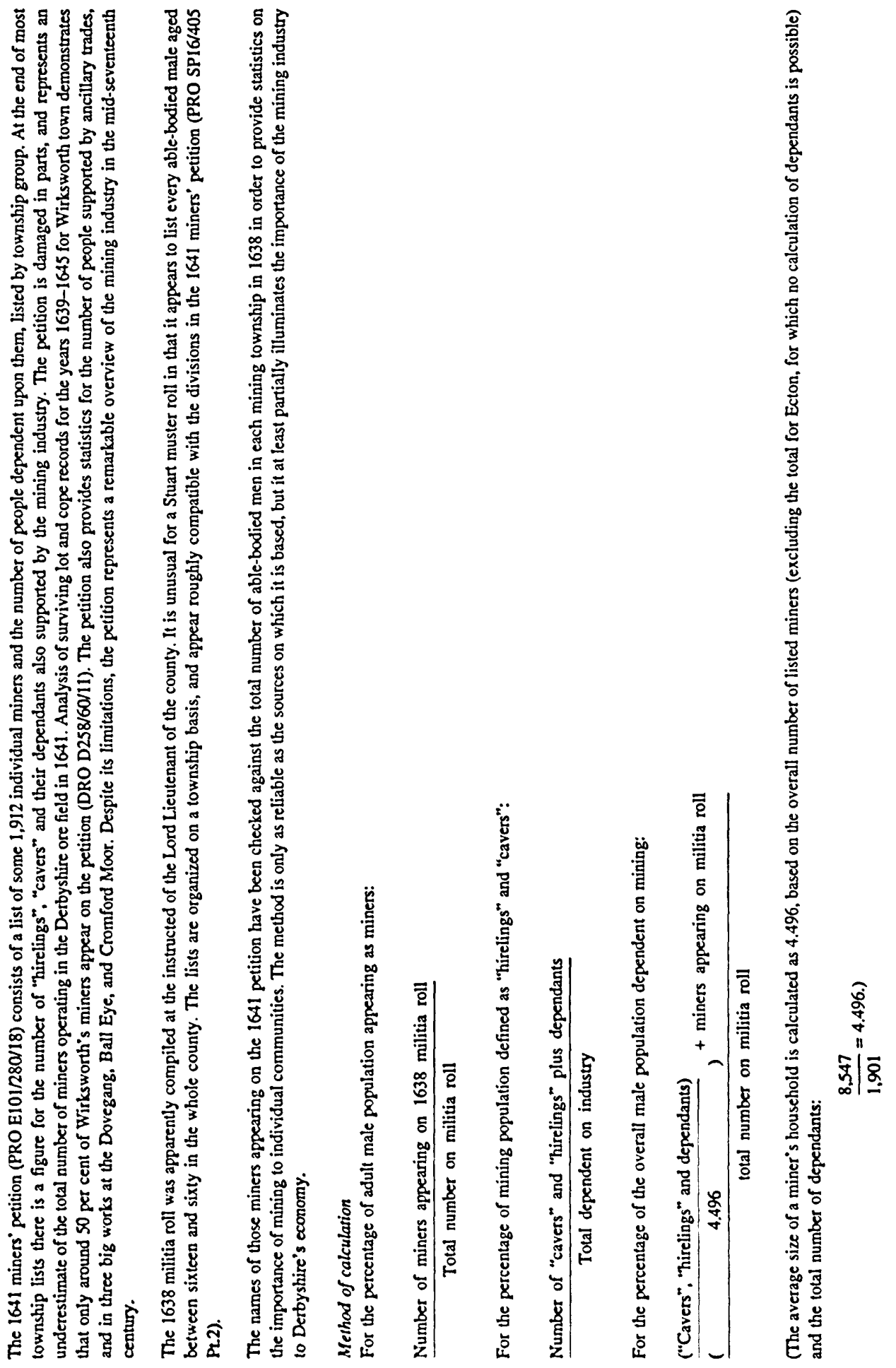




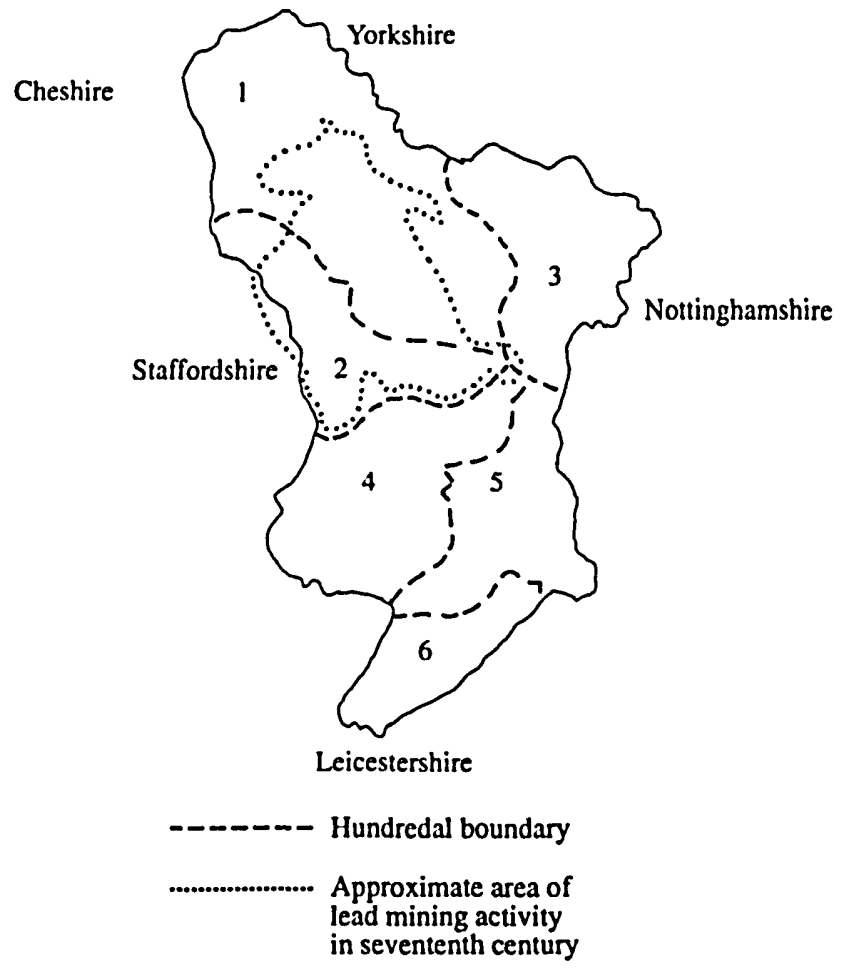

Map 1. Administrative divisions of Derbyshire

1 Hundred of High Peak

2 Wapentake of Wirksworth

3 Hundred of Scarsdale

4 Hundred of Appletree

5 Hundred of Morleston and Litchurch

6 Hundred of Repton and Gresley 


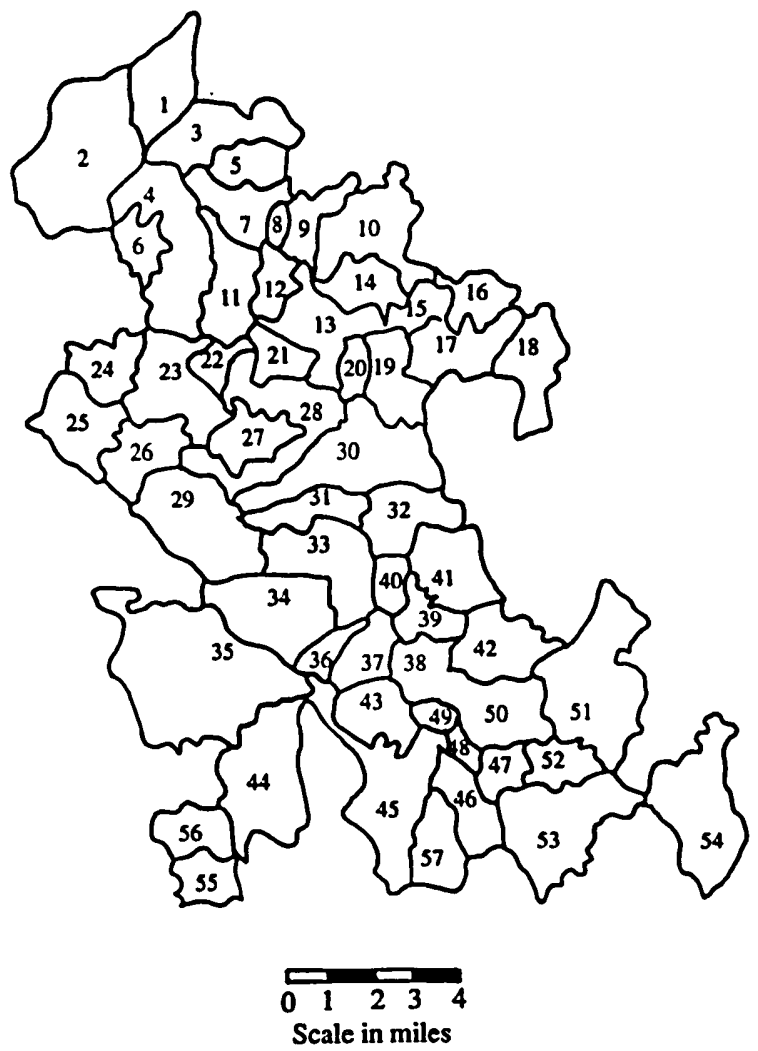

Map 2. Township boundaries of lead mining areas

1 Castleton

2 Peak Forest

3 Bradwell

4 Tideswell

5 Hazlebadge

6 Wheston

7 Great and Little Hucklow

8 Grindlow

9 Foolow

10 Eyam

11 Litton

12 Wardlow

13 Great Longstone

14 Stoney Middleton

15 Calver

16 Curbar

17 Baslow

18 Bubnell

19 Hassop
20 Rowland

21 Little Longstone

22 Brushfield

23 Taddington

24 Blackwell

25 Chelmorton

26 Flagg

27 Sheldon

28 Ashford

29 Monyash

30 Bakewell

31 Overhaddon

32 Netherhaddon

33 Youlgreave

34 Middleton-by-Youlgreave

35 Hartingdon

36 Gratton

37 Elton

38 Winster
39 Birchover

40 Harthill

41 Stanton

42 Wensley and Snitterton

43 Aldwark

44 Parwich

45 Brassington

46 Hopton

47 Middleton

48 Ible

49 Ivonbrook Grange

50 Bonsall

51 Matlock

52 Cromford

53 Wirksworth

54 Crich

55 Tissington

56 Newton Grange

57 Carsington 


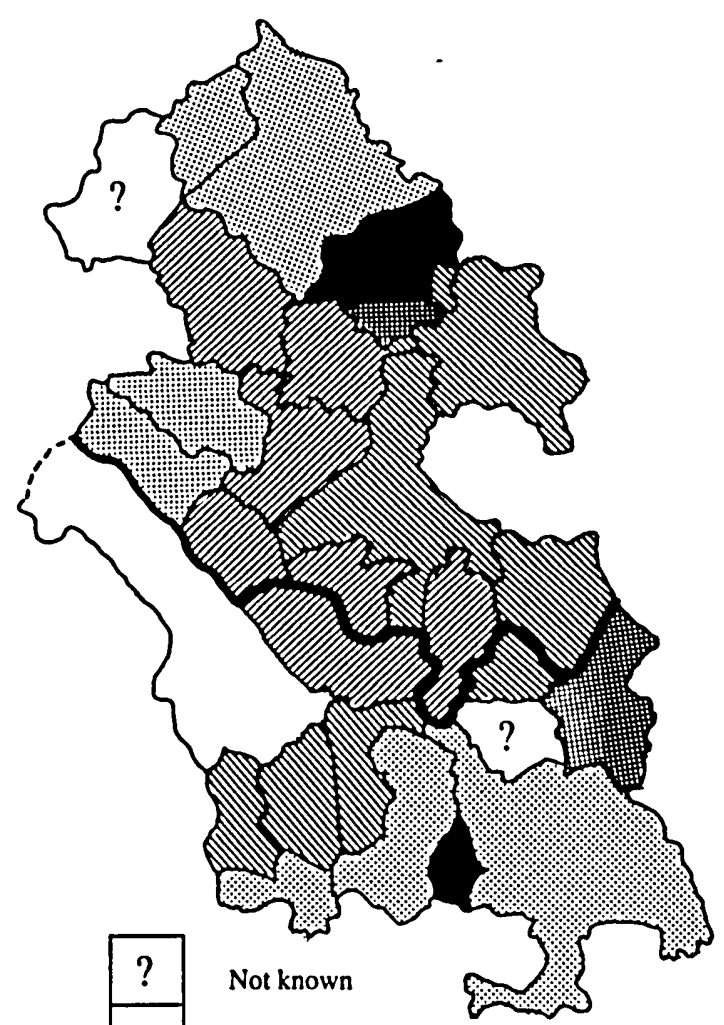

0-50\% population decline

$1-50 \%$ population growth

$51-100 \%$ population growth

$101-200 \%$ population growth

201-300\% population growth

More than $300 \%$ population growth

Boundary between Hundred of High Peak and

Wapentake of Wirksworth

Map 3. Population growth in Derbyshire's lead mining parishes, 1563-1664

Sources: PRO E179/94/403

PRO E179/94/402

BL Harl Mss 594

Following the 1563 ecclesiastical census, the map follows parish boundaries. Consequently it does not reflect the exact boundaries of Derbyshire's lead mining areas in the early modern period. 